\title{
Breast Radiology Practices During The Covid-19 Pandemic
}

\section{COVID-19 Pandemisi Sürecinde Meme Radyolojisi}

\author{
Irmak Durur Subaşı \\ İstanbul Medipol Üniversitesi, Tıp Fakültesi, Radyoloji Anabilim Dalı, İstanbul, Türkiye.
}

\section{ÖZET}

Meme kanseri taramasının en önemli amacı, kanserin erken evrede yakalanarak meme kanserine bağlı ölümlerin azaltılmasıdır. COVID-19 salgını, hastaların ve sağlık çalışanlarının sağlık durumu ile ilgili acil bir sorun olarak kısa bir süre önce dünya gündemini ve genel kaygıları değiştirmiştir. Hala meme taramanın amacı mortaliteyi azaltmaktır; ancak bunun COVID-19 (SARS-COV-2) kaynaklı ölümlere neden olmaması için ayrıntılı rehberler oluşturulmalıdır.

Anahtar Kelimeler:biyopsi, mamografi, meme ultrasonografisi, SARS-COV-2

\section{ABSTRACT}

The most important goal of breast cancer screening is to detect cancer at an early stage and reduce deaths due to breast cancer. The COVID-19 pandemic has recently changed the world agenda and general concerns as an urgent issue regarding the health status of patients and healthcare workers. Still, the goal of breast screening is to reduce mortality; However, detailed guidelines should be created so that this does not cause deaths from COVID-19 (SARS-COV-2).

Key Words:biopsy, breast ultrasonography, mammography, SARS-COV-2

\section{Giriş}

Koronavirüs hastalığı (COVID-19); şiddetli akut solunum sendromukoronavirüs 2 (SARS-COV2)'nin sebep olduğu enfeksiyöz bir hastalıktır. İlk defa Aralık 2019'da Çin'in Hubei eyaletinin en büyük kenti olan Wuhan'da ortaya çıkmış ve aylar içinde bütün dünyaya yayılmıştır (1). Her ülkede, eyalette ve şehirde oluşturulmak zorunda kalınan ilgili bilim kurulları hastalıkla ilgili birçok bilinmeyen yanı sıra, kolay bulaşmasına ve belirti ve bulgu göstermeyen sağlıklı taşıyıcılara dikkat çekmektedir. $\mathrm{Bu}$ durum insanları ihtiyaçları olsa bile toplu bulunulan ortamlardan uzaklaşmaya itmektedir. Ancak yine de COVID-19 salgını varken diğer hastalıklar da devam etmektedir. Böyle bir ortamda akılcı yaklaşımlarla uygun tanı ve tedavi yöntemlerine ulaşım ön plana çıkmaktadır. Meme sağlığı tüm kadınları ve dolayısıyla tüm insanlığı ilgilendirir. Meme radyolojisi ise günlük rutin içerisinde iş yoğunluğunun bulunduğu alanlardan birini oluşturur.

TheNationalComprehensiveCancer Network (NCCN) rehberlerine göre 40 yaş üzerindeki ortalama riske sahip, asemptomatik, kadınlarda y1llık mamografi ile meme kanseri taramas1 yapılmalıdır. Ömür boyu ortalama riski artmış $(>\% 20)$ olan kadınlarda ise y1llık mamografi ve meme manyetik rezonans görüntüleme ile kanser taraması yapılmalıdır (2). Ayrıca meme ile ilgili çeşitli klinik durumlar için, oldukça ayrıntılı görüntüleme önerileri de bulunmaktadır.

$\mathrm{Bu}$ derlemede; dünyanın önde gelen meme görüntüleme derneklerinin COVID-19 pandemisinde, meme radyolojisi ile ilgili öncelikli ve ertelenebilecek durumları tespit ettiği öneri metinleri gözden geçirilerek bu işlerle ilgili sağlık çalışanlarının korunma tedbirlerine değinilecektir.

\section{Pandemide Görüntüleme Önerileri}

Avrupa Meme Görüntüleme Derneği (EuropeanSociety of BreastImaging-EUSOBI), salgın sırasında meme görüntüleme önceliklerini belirleyen "COVID-19 pandemisi sirasında ve pandemiden sonra meme hastalıklarında görüntüleme ve meme kanseri tanısı ile ilgili EUSOBI önerileri (EUSOBI recommendationsforbreastimagingandcancerdiagn 
osisduringandafterthe COVID-19 pandemic)" başlıklı bir öneri metni yayınlamıştır (3). Yazıda erken meme kanserinin mutlaka tedavi gerektiren bir durum olduğuna, ortalama risk altındaki kadınlarda meme kanserinin nispeten yavaş büyüdüğüne ve taramada kısa bir gecikmenin (örn. 6-12 hafta) bu hastalığın genel sonuçlarını olumsuz etkilemeyeceğine dikkat çekilmektedir. Durum tarama için bu şekilde iken hastaların klinik belirtilerinin bulunduğu veya tetkik sürecinin devam ettiği durumlarda; kısa süreli gecikmenin tedavi sonuçlarında önemli değişikliklere sebep olmasa da hastaların psikolojilerini etkileyebileceğine vurgu yapılmaktadır. Bu metinde yapılan önerilerin özellikle hasta ve toplum güvenliği temelinde dengelenmesine de vurgu yapılmaktadır. Genel olarak öneriler şu şekildedir (3):

- "Her ülke, bölge ve hatta şehir farklı bir dizi değişen koşulla karşı karşıya kalacak ve sağlık politikası danışmanları tarafindan faaliyetlerin zamanlaması konusunda yönlendirilecektir.

- Meme kanseri kuşkusu taşıyan belirtilere sahip kadınlar mümkün olan en kısa sürede tetkik edilmelidir.

- İgne biyopsisi endikasyonu olan kadınlar (BIRADS 4 veya 5) mümkün olan en kisa sürede bu işleme girmelidir.

- Evreleme amaçli veya tedavi sonrası kontrol amaçl tetkik edilmesi gereken meme kanseri hastalarl daha fazla gecikmeden ilgili tetkiklere girmelidir.

- Meme kanseri risk artışı olan, tarama randevusu iptal edilen ve herhangi bir belirti taşımayan kadınlara, önceki tetkikinden sonra tercihen 1 yll üç ay (15 ay) içinde bir tarama tetkiki yapılmalıdır. Ayrıca bu özelliklere sahip ve mamografi ve manyetik rezonans görüntüleme ile kombine tarama yapılan kadınlarda, manyetik rezonans görüntüleme yapılması şartıyla mamografi ile tarama bir yol için atlanabilir.

- $\quad$ Meme kanseri tedavisi gördükten sonra yıllık olarak mamografi ile takip yapılan ve herhangi bir belirti taşımayan kadınların kontrol randevuları, önceki tetkikinden sonra tercihen 1 yıl üç ay (15 ay) içinde planlamalıdır; bireysel nüks riskine bağll olarak bir yıla kadar bir gecikme kabul edilebilir.

- COVID-19 salgınının başlangıcından sonra mamografi taramasi yapilamayan ve herhangi bir belirti taşımayan kadınların tetkikleri, söz konusu randevularindan sonra tercihen 3-6 ay içinde yapılır. Ortalama bir riske sahip kadınlarda yıllık tarama için bir yıla kadar bir gecikme kabul edilebilir."
$\mathrm{Bu}$ metnin esas olarak memenin taranması, teşhisi ve tedavisi ile sınırlı olduğuna, tüm vücut onkolojik görüntüleme önerilerinin genel onkolojik görüntüleme önerilerine birakıldığına da değinilmektedir (www.esmo.org, www.asco.org). Yine de bu metin, diğer öneri kaynakları arasında memeye ait klinik durumlar ile ilgili en ayrıntılı belirleme sayllabilir.

Ayrıca Kanada Meme Görüntüleme Derneği (TheCanadianSociety of BreastImaging-CSBI) ve Kanada Radyoloji Derneği (CanadianAssociation of Radiology-CAR), COVID-19 pandemisi sırasında uyulması gereken ilkeleri açıklamış ve öncelikle korunma tedbirlerine dikkat çekilmiştir (4). COVID-19 için başlica enfeksiyon mekanizmaları solunum damlacıkları ve tükürüktür. Bu nedenle bu mekanizmanın işlemesini engelleyen maske kullanımı kuralına, semptomlardan bağımsız olarak bütün hastalar uymalıdır. Meme görüntüleme bölümlerinde hastalar ile yakın çalışan ve fiziksel teması olan tüm personel, cerrahi maske, önlük ve tek kullanımlık eldivenler giymeli, siperlik veya gözlük takmalıdır. N95 maskeleri, yalnızca doğrulanmış veya şüpheli COVID-19 hastalarında,aerosol oluşan işlemlere saklanmalıdır. Karantina dönemlerinde ideal olmasa da evden raporlama yöntemine geçilmiş ise mamografi değerlendirilmesi için 5megapiksel ekran kullanımından vazgeçilmemelidir. Süreç uzarsa ekranlar zaman zaman fizik mühendislerince kontrol edilmelidir (4).

Meme görüntülemede düşük öncelikli durumlar "karantina kaldırılıncaya kadar" ertelenmelidir. Bunlar, belirtisiz hastalarda meme taramas1, meme kanserinden tedavi görmüş hastalarda y1llık takip, diğer bulguların yokluğunda meme ağrısı (özellikle döngüsel ve iki taraflı), radyologların değerlendirme veya biyopsi açısından geciktirmede sakınca görmedikleri lezyonlar, kısa süreli takipler, çok genç (25 yaş altı)hastalardaki kuşkulu olmayan lezyonların takibi, jinekomasti değerlendirilmesi, silikon bütünlüğünün değerlendirilmesi ve kist drenajıdır.

Yüksek öncelikli durumlar ise meme apsesi gibi drenaj gerektiren durumlar, inflamatuar veya lokal ileri meme kanserine dair klinik şüphe, gebelikle ilişkili meme kanseri şüphesi, multidisipliner konseyde tartışılan ve kritik olduğu belirlenen vakalar, kitle, ciltte kalınlaşma, gamze, kanlı veya sulu (süt gibi olmayan) meme başı akıntısı, aksiller kitle veya lenfödem bulgularından birinin yeni gelişmesi, meme ucunun sonradan içe dönmesidir. $\mathrm{Bu}$ durumlar da acil değerlendirme olarak kabul edilmemeli; COVID-19 tanılı, semptomlar nedeniyle COVID-19 şüpheli, 14 günlük izolasyon süresi içindeki hastaların veya COVID-19 hastası ile yakın temasta bulunmuşkişilerin meme görüntüleme randevusu 14 gün veya yerel halk 
sağlığ1 yetkililerinin önerdiği şekilde ertelenmelidir (4). Amerika Meme Görüntüleme Derneği (Society of BreastImaging-SBI), öncelikle, her şehir ve eyaletin farklı koşullarla karşı karşıya bulunduğu bir halde; meme görüntüleme pratiğini yeniden başlatmak için kararın lokal bazda alınmasına dikkat çekmektedir (5). Bazı tesisler, bölgelerinde hala çok sayıda COVID-19enfeksiyonuyla başa çıkmaya çalışırken, daha az etkilenen bölgelerdeki uygulamalar, görüntüleme pratiğini yakında yeniden başlatmak için hazırlıklar yapıyor olabilir. Önemli olan güvenli zamanlamanın sağlanmasıdır. Enfeksiyon dalgasının toplumdaki derinliği-hasta yoğunluğu, ilgili bölgeye ait karantina, sokağa çıkma yasağı ve kısitlamalar, tesislerin durumu, kişisel korunma ekipmanlarının ulaşılabilirliği ve uygun sosyal mesafeyi sürdürme yeteneği gibi birçok faktöre bağlı olarak değişiklik gösterecektir. Meme görüntülemeyi yeniden başlatma kararı, cerrahların, onkologların ve radyasyon onkologlarının yeni teşhis konmuş hastaları kabul etme kapasitesini de hesaba katmalıdır (5).

Güvenli meme görüntüleme uygulaması için öneriler ise(5);

- Her hastayl COVID-19maruziyeti veya semptomlarl için tesise girmeden hemen önce tarayın ve yalnızca COVID-19 tarama sürecini tamamlamış hastalarla devam edin.

- Bekleme sirasinda topluca bulunmayı önlemek için randevu sayllarınıCOVID-19 öncesi seviyelere göre azaltın.

- Tekrarlayan salgin riski belirgin şekilde azaldığındaCOVID-19 öncesi seviyelere dönün.

- Bekleme ve soyunma odalarinda sosyal mesafenin korunabilmesi için şartları düzenleyin.

- Hastaların tesiste kaldığı süreyi sınırlandırmak için kayıt, giriş ve çıkışsaatlarini değerlendirin ve düzenleyin.

- Personel sayısını değerlendirin ve bu sayıyı her hasta için mümkün olan asgari sayı ile sinirlayın.

- Personelin ve hastaların tüm ziyaretler için maske takmasını să̆layın.

- Kişisel korunma ekipmanlarınıdeğerlendirin.

- Hastalarin tesis ziyaretlerinin süresini ve sayısını azaltmak için kolaylaştırılmış veya klsaltılmış görüntüleme protokolleri uygulamayı düşünün (kısaltılmış MRI protokolleri, aynı gün tarama yorumu, aynı gün biyopsi performansi gibi).

\section{Sonuç}

Dünya Sağlık Örgütü verilerine göre COVID-19 salgını, her geçen gün dünyada daha çok kişiyi etkilemektedir. Bazı kontrol ölçekleri bildirilse de COVID-19 pandemisi, hala sağlık sistemlerini zorlamakta ve hizmetlerin ihtiyaca göre şekillenmesini kaçınılmaz kılmaktadır.Pandemi ilerledikçe, viral bulaş ve sağllk sistemi üzerindeki etkisi hakkında giderek daha fazla bilgi edinilmekte ve rehberler de zaman zaman güncellenmektedir. Salgının başlangıcından bu yana her ülkenin, bölgenin, il-ilçe-köy bazında yerleşim yerinin ve hatta sağlı tesisinin kendi gerçeği ortaya çıkmaktadır. EUSOBI, CSBI, CAR, SBI önerileri, genel olarak tanımlandıkları coğrafyaların ihtiyaçlarına göre şekillendirilmiştir, birbirlerini tamamladıkları kabul edilebilir. $\mathrm{Bu}$ öneriler Türkiye'de sağlı hizmetini vermeye devam eden sağlık profesyonellerine kendi yönergelerini oluşturmada rehberlik etmesi amacı ile bir araya getirildi.

Son olarak, hastaların ve sağlık çalışanlarının bu dönemde maske ve siperlik gibi kişisel korunma ekipmanlarını uygun şekilde kullanmaları önem taşımaktadır. Meme Radyolojisi pratiğinde özellikle mamografi, ultrasonografi ve biyopsi işlemlerinde hasta ve sağlık çalışanının belirli bir süre sosyal ya da fiziksel mesafeyi koruyamayacak şekilde yakın bulunması gerektiğinden kişisel korunma ön plana çıkmaktadır. 


\section{Kaynaklar}

1. Tokgöz Akyıl F, Karadoğan D, Gündüz Gürkan C, et al. WhatWeLearnedabout COVID-19 So Far? Notesfrom Underground. TurkThorac J 2020; 21(3): 185-92.

2. NationalComprehensiveCancer

Network

(NCCN)ClinicalPracticeGuidelines in Oncology. (2019).NCCN BreastCancerScreeningandDiagnosis. https://www.nccn.org/professionals/physician_gls/p df/breast-screening.pdf\#Page $=7$

3. FedericaPediconi, Ritse M. Mann, Fiona J. Gilbert, GaborForrai, FrancescoSardanelli, Julia CampsHerrero, on behalf of the EUSOBI Executive Board. EUSOBI recommendationsforbreastimagingandcancerdiagnos isduringandafterthe

COVID-19 pandemic.https://www.eusobi.org/news/recommend ations-breast-covid19/\#more-4600

4. TheCanadianSociety of BreastImaging (CSBI) andtheCanadianAssociation ofRadiology (CAR) GuidelinesforBreastImagingduringthe COVID-19 Pandemichttps://car.ca/wpcontent/uploads/2020/04/CARCSBI_Breast_Imaging_Guidelines_During_COVID -19_2020_04_02_EG.pdf

5. Society of breastimaging. Society of BreastImaging Statement on BreastImagingduringthe COVID-19 Pandemic. https://www.sbionline.org/Portals/0/Position\%20Statements/2020/so ciety-of-breast-imaging-statement-on-breastimaging-during-COVID19-pandemic.pdf 